\title{
Sosialisasi Zero Waste dan Coaching Clinic Pengolahan Sampah di Desa Labuhan Haji
}

\author{
Agus Muliadi Putra ${ }^{1}$, Baiq Liana Widiyanti², Husnayati Hartini*3 ${ }^{2}$, Haerudin ${ }^{4}$ \\ amp.ocean@gmail.com ${ }^{1}$, husnayatihartini@ hamzanwadi.ac.id*3 \\ ${ }^{1234}$ Program Studi Teknik Lingkungan, Fakultas Teknik, Universitas Hamzanwadi
}

Received: 30 Mei 2021

DOI: 10.29408/ab.v2i1.3569
Accepted: 16 Juli $2021 \quad$ Online Published: 31 Juli 2021

URL: http://dx.doi.org/10.29408/ab.v2i1.3569

\begin{abstract}
Abstrak: Setiap aktivitas yang dilakukan manusia akan selalu menghasilkan sisa yang disebut dengan sampah dan limbah. Sampah biasanya identik dengan sisa pengolahan sehari-hari yang berbentuk padat, sedangkan limbah merupakan sisa pengolahan yang berbentuk cair. Baik sampah dan limbah keberadaannya diperkirakan akan terus meningkat seiring dengan meningkatnya aktivitas manusia dan pertambahan penduduk. Merubah cara pandang masyarakat tentang limbah dari anggapan sebagai bahan buangan yang tidak mempunyai manfaat menjadi bermanfaat merupakan salah satu bagian yang tidak terpisahkan dari upaya edukasi dan sosialisasi Zero Waste. Tujuan dari kegiatan ini adalah untuk sosialisasi masyarakat Desa Labuhan Haji tentang Zero Waste. Sosialisasi ini terdiri dari tiga kegiatan yaitu: 1) edukasi tentang materi Zero Waste; 2) demonstrasi atau praktik pengolahan limbah minyak jelantah menjadi lilin dan sabun; 3) coaching clinic tentang pengolahan sampah (pengumpulan, pemilahan, penimbangan, dan analisis komposisi sampah). Metode yang digunakan yaitu ceramah, demonstrasi, praktik, dan diskusi. Lokasi kegiatan di Desa Labuhan Haji dan Lab. Program Studi Teknik Lingkungan, Fakultas Teknik, Universitas Hamzanwadi. Hasil pelaksanaan kegiatan menunjukkan adanya peningkatan pengetahuan dan kesadaran akan pentingnya program Zero Waste pada masyarakat Desa Labuhan Haji. Selain itu masyarakat mampu mengolah minyak jelantah menjadi bahan yang lebih berguna, dan mampu mengolah sampah dengan baik.
\end{abstract}

Kata Kunci: Coaching Clinic; Limbah; Pengolahan Sampah; Zero Waste

\begin{abstract}
Every human activity will always produce residues called garbage and waste. Garbage is usually identical to the rest of daily processing in solid form, while waste is the rest of the processing in liquid. Both waste and garbage will continue to increase in line with increasing human activities and population growth. Changing the public's perspective on waste from being considered a waste material that has no benefits to being helpful is an integral part of Zero Waste education and socialization efforts. The purpose of this activity is to socialize the people of Labuhan Haji Village about Zero Waste. This socialization consists of three activities, namely: 1) education about Zero Waste materials; 2) demonstration or practice of processing waste cooking oil into candles and soap; 3) coaching clinic on waste management (collection, sorting, weighing, and analysis of waste composition). The method used is lecture, demonstration, practice, and discussion. Location of activities in Labuhan Haji Village and Lab. Environmental Engineering Study Program, Faculty of Engineering, Hamzanwadi University. The implementation of the activity showed an increase in knowledge and awareness of the importance of the Zero Waste program in the people of Labuhan Haji Village. In addition, the community can process used cooking oil into more valuable goods and process waste properly.
\end{abstract}

Keyword: Coaching Clinic; Waste Management; Waste Processing; Zero Waste 


\section{PENDAHULUAN}

Zero waste merupakan sebuah konsep pengelolaan sampah berbasis daur ulang (Wirasasmita, dkk., 2020). Daur ulang di sini dapat diartikan sebagai proses perancangan dan pengelolaan kembali suatu produk untuk menghindari atau menghilangkan sampah dan limbah sehingga sumber daya alam yang terkena dampak buruk akibat sambah dan limbah dapat pulih kembali. Selain itu zero waste dijadikan sebagai gaya hidup bersih dengan meminimlkan sampah dan limbah. Zero waste juga dapat dijadikan sebagai strategi dalam membantu perekonomian masyarakat dengan cara memproduksi dan mengkonsumis sekaligus menghargai sistem ekologi dan komponen yang terdapat di dalamnya. Sehingga seluruh material yang ada pada ekologi tersebut dapat kembali ke alam dengan aman dan berkelanjutan (Prajati \& Darwin, 2017). Zero waste sendiri memiliki ruang lingkup yang terdiri dari beberapa konsep yang dikembangkan sebagai sebuah sistem pengolahan sampah yang berkelanjutan. Beberapa dari konsep tersebut antara lain menggunakan kembali, menghindari, regenerasi, mengurangi, memproduksi kembali, memperbaiki, mendistribusikan dan menjual kembali berbagaimacam sumber sampah. Tujuan zero waste sendiri tidak hanya mendorong proses daur ulang akan tetapi lebih kepada mengatur dan merancang kembali serta mendistribusikan produk guna pencegahan dan pengurangan sampah (Zaman, 2014).

Pemerintah Indonesia telah mengatur tentang pengelolaan sampah dalam UU No 18 tahun 2008 tentang pengelolaan sampah. Pada undang-undang tersebut dijelaskan bahwa sampah merupakan sisa berbentuk padat dari kegiatan manusia dan atau proses alam. Hal ini menyiratkan bahwa segala aktifitas manusia dapat menghasilkan sampah. Sehingga timbunan sampah akan semakin bertambah seiring perkembangan jumlah dan aktivitas manusia. Oleh karena itu persoalan yang timbul dari hal tersebut semakin mendesak untuk diselesaikan. Bukan hanya karena berdampak pada lingkungan yang tidak seimbang akan tetapi kesehatan manusia juga terancam. Cara pandang dan pola fikir manusia terhadap sampah mengakibatkan tingkat kepedulian dan kesadaran manusia terhadap dampak negatif sampah menjadi rendah. Masayarakat cendrung membuang sampah sembarangan sehingga mengakibatkan perilaku hidup dan lingkungan yang tidak sehat. Merubah cara pandang masyarakat mengenai sampah dapat dilakukan secara terpadu, yaitu dengan merubah pola fikir masyarakat ynag menganggap sampah merupakan bahan yang tidak memiliki manfaat dan faedah menjadi pola fikir yang menganggap sampah memilik manfaat yang besar bagi kehidupan jika dikelola dengan baik (Trihadiningrum, 2008).

Wilayah pesisir dan laut merupakan daerah dataran rendah yang paling berpotensi menerima kerugian terbesar dalam masalah sampah. Betapa tidak, sampah-sampah dari daerah hulu akan terangkut dan terbawa oleh aliran sungai menuju ke daerah pesisir dan laut. Menurut data Asosiasi Industri Pasifik Indonesia dan BPS dalam Kompas (2019), dari 64 juta ton/tahun sampah plastik yang dihasilkan, 3,2 ton dibuang ke laut. Dengan berbagai dampak kerusakan yang diakibatkan oleh sampah di pesisir dan laut ini, tentunya tidak ada acara lain bagi umat manusia selain mengurangi produksi dan penggunaan sampah plastik itu sendiri.

Berangkat dari konsep pengelolaan sampah secara terpadu, maka hal yang dilakukan pertama kali adalah pemilahan sampah. Memilah sampah mulai dari sumbernya atau lingkungan masing-masing saat ini seharusnya sudah menjadi bagian dari gaya hidup masyarakat. Dengan tumbuhnya kesadaran untuk memilah sampah saja, sebagian persoalan 
sampah bisa teratasi. Pemilahan dan pemanfaatan sampah harus menjadi tanggung jawab bersama antara pemerintah, masyarakat, dan pemangku kepentingan lainnya. Setidaknya, yang seharusnya sudah berjalan adalah memilah sampah organik dan non organik sejak dari sumber. Pengolahan sampah yang modern sekalipun tetap sulit dijalankan jika sampah tidak terpilah, sehingga perlu ditumbuhkan kesadaran ditengah-tengah masyarakat akan pentingnya memilah sampah yang dimulai dari sumber.

Salah satu cara mengubah sampah menjadi barang yang berguna adalah dengan memanfaatkan sampah/limbah minyak jelantah sebagai bahan baku pembuatan sabun dan lilin. Minyak jelantah merupakan salah satu limbah sisa penggorengan yang hampir kita temukan setiap hari dirumah. Selain itu banyaknya aktivitas warga di rumah akibat pandemi COVID-19 yang menghabiskan waktu untuk melakukan kegiatan di dapur atau memasak. Hal ini menyebabkan limbah minyak jelantah semakin meningkat. Limbah minyak jelantah apabila dibuang langsung ke lingkungan akan menyebabkan terjadinya pencemaran. Selain itu minyak jelantah jika terus dikonsumsi akan menimbulkan banyak penyakit karena mengandung senyawa yang berbahaya.

Berdasarkan uraian diatas maka perlu adanya kegiatan edukasi dan pelatihan tentang pemanfaatkan sampah/limbah rumah tangga menjadi barang yang berguna kepada masyarakat serta edukasi tentang pemilahan sampah dengan harapan dapat memberikan pengetahuan tentang urgensi dan memiliki keterampilan cara pemilahan sampah. Dengan adanya kegiatan pengabdian ini juga diharapkan dapat mendukung dan membantu program zero waste Pemerintah Provinsi Nusa Tenggara Barat yang dimana salah satu kunci keberhasilan kegiatan zero waste tersebut adalah dimulai dari pemilahan sampah.

Tujuan dari kegiatan pengabdian ini secara lebih detail yaitu sebagai berikut: 1) Meningkatkan pengetahuan, kesadaran, sikap, dan partisipasi masyarakat terhadap pola hidup zero waste dalam kehidupan sehari-hari di lingkungan keluarga dan sekitar tempat tinggal; 2) Meningkatkan pengetahuan, kesadaran, sikap, keterampilan, dan partisipasi generasi muda dan pelajar terhadap penanganan sampah secara umum, dan pemilahan sampah secara khusus; 3) Memberikan pelatihan kepada masyarakat tentang pemanfaatan limbah minyak jelantah menjadi barang yang berguna (lilin dan sabun); 4) Membangun jejaring komunikasi dalam rangka transfer ilmu pengetahuan antara universitas dengan masyarakat melalui kegiatan pelayanan dan kegiatan yang bermanfaat bagi masyarakat.

Dari tujuan di atas, kegiatan ini diharapkan memberikan manfaat kepada masyarakat berupa: 1) masyarakat mendapat ilmu dan pengetahuan tentang pola hidup zero waste seperti bagaimana memanfaatkan limbah rumah tangga; 2) para generasi muda dan pelajar mendapat ilmu dan pengetahuan tentang penanganan sampah secara umum serta pemilahan sampah secara khusus.

\section{METODE PELAKSANAAN} Waktu dan Lokasi

Kegiatan Pengabdian Kepada Masyarakat ini dilaksanakan mulai Bulan Mei Tahun 2020 sampai dengan Bulan Oktober 2020, pelaksanaan kegiatan ini bertempat di Desa Labuhan Haji dan Laboratorium Alam Program Studi Teknik Lingkungan Universitas Hamzanwadi, Kabupaten Lombok Timur. 


\section{Prosedur pelaksanaan}

\section{A. Metode Pelaksanaan}

Guna mendukung realisasi program kerja, maka metode pelaksanaan kegiatan pengabdian ini secara keseluruhan meliputi tahapan sebagai berikut:

1. Tahapan Awal

Pelaksanaan pengabdian ini diawali dengan melakukan survey dan koordinasi dengan mitra pengabdian yaitu Pokdarwis "Silatama" dan SMAN 1 Labuhan Haji. Pokdarwis adalah kelompok sadar wisata yang beranggotakan masyarakat baik laki-laki maupun perempuan usia produktif (terdiri atas para pemuda, ibu rumah tangga, tokoh masyarakat). Sedangkan partisipan di SMAN 1 Labuhan Haji terdiri atas siswa kelas X SMAN 1 Labuhan Haji sebanyak 15 orang. Koordinasi dan diskusi diadakan untuk mematangkan agenda kegiatan pengabdian. Pada tahap ini juga dilakukan persiapan alat dan bahan untuk sosialisasi dan coaching clinic pemilahan sampah.

2. Tahapan Pelaksanaan

a. Sosialisasi dan Edukasi Tahap 1

Pada tahap ini dilakukan kegiatan sosialisasi tentang pola hidup zero waste dengan tema "pemanfaatan minyak jelantah menjadi barang berguna". Materi dibuat dalam bentuk presentasi dengan konsep penyampaian semenarik mungkin dengan harapan para peserta mudah memahami materi tersebut. Para peserta pada tahapan ini adalah perwakilan anggota pokdarwis sebanyak 5 orang dan perwakilan masyarakat disekitar lokasi wisata Pantai Labuhan Haji sebanyak 5 orang.

b. Metode Demontrasi/Praktek.

Pada tahap ini dilakukan praktek pembuatan sabun dan lilin berbahan minyak jelantah. Metode ini digunakan untuk menjelaskan cara sederhana pengolahan minyak jelantah menjadi barang lain yang bisa dimanfaatkan kembali. Kegiatan ini dibantu juga oleh mahasiswa Program Studi Teknik Lingkungan. Minyak jelantah mengandung senyawa karsinogenik dan persidannya meningkat akibat proses penggorengan dan termasuk bilangan asam, sehingga minyak jelantah termasuk dalam golongan limbah (Erviana, 2019). Senyawa karsinogenik merupakan senyawa yang dapat menyebabkan kangker jika dikonsumi terus menerus. Zat ini juga terdapat pada makanan yang mengandung formalin (Fatmawati, dkk., 2020). Limbah minyak jelantah yang diperoleh dari sisa minyak dari proses penggorengan berulang kali mengakibatkan asam lemak yang terkandung di dalamnya akan semakin jenuh sehingga tidak sehat lagi untuk dikonsumsi (Kusumaningtyas, dkk., 2018). Pecahnya trigliserida menjadi komponen volatil dan non volatil yang larut dalam minyak menjadikan kulitas minyak goreng menjadi menurun sehingga mempengaruhi cita rasa dan aroma makanan yang digoreng menggunakan minyak jelantah (Mardiana, dkk., 2020).

1. Pembuatan sabun minyak jelantah

Prosedur pembuatan sabun dari minyak jelantah mengacu pada Ginting, dkk (2020). Adapun bahan-bahan yang digunakan adalah larutan $\mathrm{NaOH}$, arang aktif dan fragrance atau bahan pewangi. Sedangkan alat-alat yang dibutuhkan dalam 
pembuatan sabun adalah wadah, saringan, timbangan dan wadah /alat cetak untuk mencetak sabun. Tahapan dalam pembuatan sabun minyak jelantah yaitu pada tahap awal minyak jelantah dimurnikan terlebih dahulu dengan menggunakan arang aktif dari arang kayu dengan cara didiamkan selama 1 malam (arang dan minyak dengan perbandingan 1:4). Minyak jelantah yang sudah murni disaring kemudian ditambahkan $\mathrm{NaOH}$ sambil diaduk pelan-pelan hingga mengental. Untuk mendapat sabun yang wangi bisa ditambahkan dengan fragarance oil kemudian sabun dicetak dengan alat pencetak. Setelah itu sabun di jemur di bawah sinar matahari agar menjadi lebih padat, setelah padat sabun dilepaskan dari cetakan. Sabun sudah bisa digunakan.

2. Pembuatan lilin minyak jelantah

Alat dan bahan yang digunakan dalam pembuatan lilin dari minyak jelantah adalah minyak jelantah, lilin ukuran bebas, wadah gelas atau kaleng bekas, pewarna, sumbu dari benang kasur, timbangan, paraffin, wajan, dan kompor. Cara pembuatan lilin yaitu tahap awal paraffin dihaluskan, timbang paraffin 400gr dan dimasukkan ke dalam minyak jelantah (400ml) yang sudah dipanaskan bersama pewarna dan lilin batangan. Siapkan wadah tahan panas, kemudian tuangkan campuran minyak jelantah. Diamkan beberapa saat sampai campuran menjadi hangat, setelah itu dipasangkan sumbu. Lilin kemudian didiamkan sampai menjadi dingin dan siap digunakan (Yolanda, 2019).

3. Sosialisasi dan Edukasi Tahap 2

Pada tahapan ini dilakukan kegiatan sosialisasi dan diskusi tentang pengelolaan sampah. Kegiatan ini dilakukan di Field Lab. Program Studi Teknik Lingkungan Kampus Fakultas Teknik Universitas Hamzanwadi dengan mengundang perwakilan siswa kelas X. Kegiatan sosialisasi dilaksanakan secara langsung yang dipadukan dengan kegiatan coaching clinic pemilahan sampah. Peserta dari siswa dibatasi (15 orang siswa ditambah 10 orang mahasiswa Program Studi Teknik lingkungan) dengan tujuan mengurangi kerumunan massa karena waktu pelaksanannya bertepatan dengan masa pandemi covid 19. Dalam sosialisasi ini siswa sebagai kelompok sasaran sedangkan mahasiswa membantu tim PKM dalam sosialisasi.

\section{c. Coaching Clinic Pemilahan Sampah}

Kegiatan Coaching Clinic yang dilakukan mengacu pada Kurniaty, dkk (2016) dimana pada kegiaatan ini dilakukan edukasi pemilahan sampah sambil memberikan materi sosialisasi dan edukasi yang berisikan penjelasan pengetahuan tentang kelompok dan jenis sampah seperti sampah organik dan sampah nonorganik, sampah daur ulang dan jenis sampah residu, serta cara penanganannya. Kegiatan terakhir adalah pendampingan pemilahan sampah dan pembuatan tempat sampah organik dari kawat.

\section{B. Metode Pendekatan}

Adapaun metode pendekatan yang digunakan mengacu pada metode Participatory Learning and Action (PLA) atau proses belajar dan praktek secara partisipatif. PLA merupakan bentuk baru dari metode pemberdayaan masyarakat yang dahulu dikenal sebagai "learning by doing" atau belajar sambil bekerja. Secara singkat, PLA merupakan 
metoda pemberdayaan masyarakat yang terdiri dari proses belajar tentang suatu topik kemudian setelah itu diikuti aksi atau kegiatan riil yang relevan dengan materi yang sudah dipelajari (Mardikanto dan Soebiato, 2012). Melalui teknik PLA, maka beberapa manfaat yang diharapkan adalah sebagai berikut :

1. Warga masyarakat atau siswa akan memperoleh banyak pengetahuan yang berbasis pada pengalaman yang dibentuk dari lingkungan kehidupan sekolah sehari-hari.

2. Warga masyarakatatau siswa akan berpandangan bahwa mereka sendiri mampu untuk mengemukakan masalah dan solusi yang tepat

3. Melalui PLA, orang luar dapat memainkan peran penghubung antara warga dengan lembaga lain yang diperlukan. Disamping itu, mereka dapat menawarkan keahlian tanpa harus memaksakan kehendaknya

\section{HASIL DAN PEMBAHASAN}

HASIL

\section{A. Sosialisasi dan Demonstrasi Zero Waste}

1. Sosialisasi dan Edukasi

Kegiatan sosialisasi pola hidup zero waste pada tahapan ini mengambil tema "Pemanfaatan Minyak Jelantah Menjadi Barang Berguna". Hal ini dilatarbelakangi oleh banyaknya sisa-sisa minyak goreng yang sudah tidak terpakai lagi terbuang begitu saja yang nantinya menambah potensi terjadinya pencemaran lingkungan. Selain itu jika dikonsumsi terus menerus minyak jelantah dapat memicu terjadinya berbagai macam penyakit, seperti kangker dan gangguan jantung (Hanum, 2016). Pada kenyataannya pengetahuan masyarakat tentang bahaya penggunaan minyak jelantah masih rendah, oleh karena itu perlu diadakannya sosialisasi dan eduaksi pemanfaatan dan pengolahan limbah minyak jelantah menjadi barang yang lebih berguna dan sehat.

Materi dibuat dalam bentuk presentasi dengan konsep penyampaian semenarik mungkin dengan harapan para peserta mudah memahami materi tersebut. Para peserta pada tahapan ini adalah perwakilan anggota pokdarwis sebanyak 5 orang dan perwakilan masyarakat disekitar lokasi wisata Pantai Labuhan Haji sebanyak 5 orang. Respon dan antusias dari peserta cukup baik, pelaksanaaan sosialisasi dan transformasi pengetahuan dari tim PKM berjalan lancar.

\section{Demonstrasi dan simulasi}

Setelah melakukan sosialisasi dan edukasi, tim PKM kemudian mendemonstrasikan teknik membuat sabun dan lilin dari minyak jelantah kepada para peserta. Dalam proses penjernihan minyak jelantah dapat juga digunakan kulit pisang agar lebih ramah lingkungan (Erviana, 2019) selain itu juga dalam pembuatan sabun dapat dimurnikan dengan menggunakan karbon aktif agar dapat menghasilkan warna yang sesuai (Mardiana, dkk., 2020).

Setelah tim PKM melakukan demonstrasi kemudian para peserta juga diberikan waktu melakukan simulasi dan praktek pembuatan sabun dan lilin secara mandiri dengan didampingi oleh tim dan mahasiswa untuk mengetahui tingkat pemahaman dan pengetahuan mereka sambil sesekali mengajukan pertanyaan sebagai feedback untuk mendapatkan informasi dari peserta pengabdian tentang tingkat pengetahuan 
pemanfaatan limbah rumah tangga minyak jelantah yang telah disosialisasikan sebelumnya.
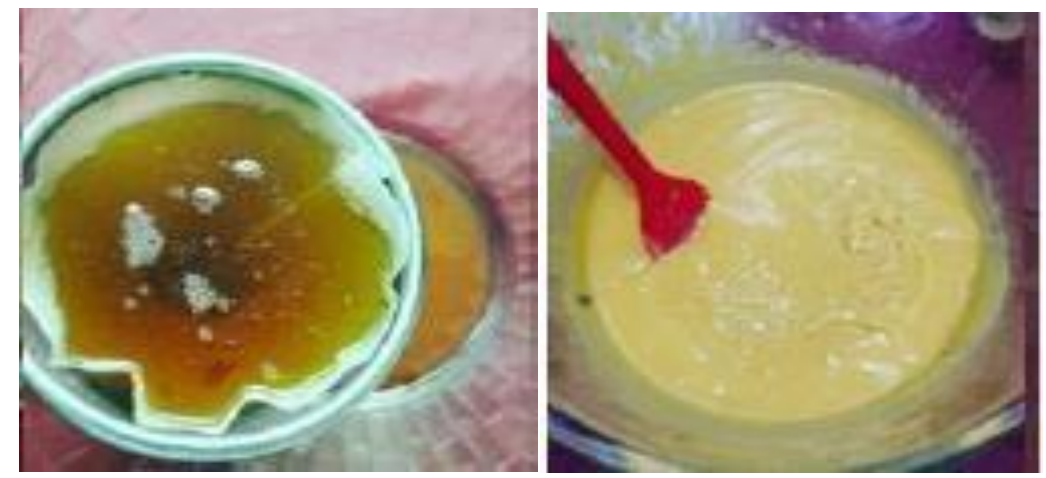

Gambar 1. Proses pembuatan sabun minyak jelantah

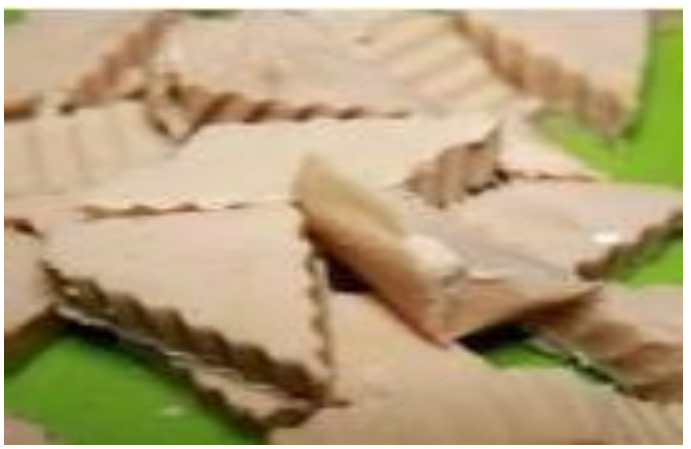

Gambar 2. Sabun dari minyak jelantah yang sudah jadi

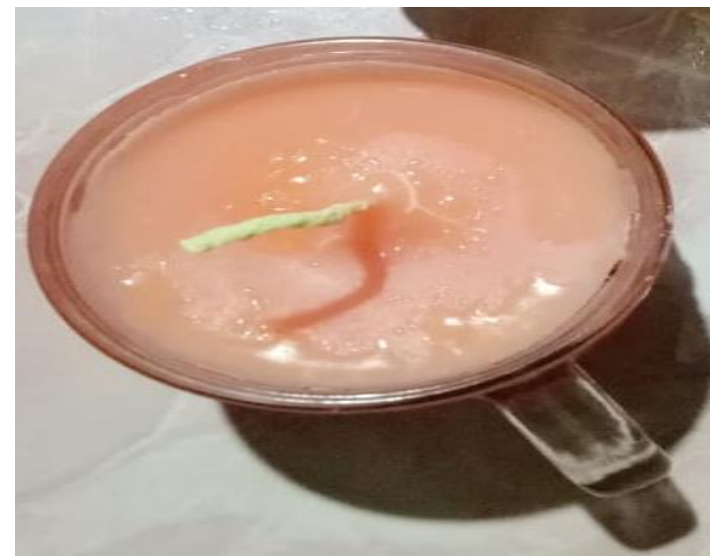

Gambar 3. Lilin dari minyak jelantah yang sudah jadi

\section{B. Coaching Clinic Pemilahan Sampah}

Kegiatan coaching clinic pemilahan sampah ini merupakan salah satu kegiatan partisipatif yang melibatkan siswa kelas X SMAN 1 Labuhan Haji dan mahasiswa Program Studi Teknik Lingkungan. Kegiatan ini dipandu langsung oleh tim PKM dan bertempat di fieldLab (Laboratorium Lapangan) program studi Teknik Lingkungan Universitas Hamzanwadi. Peserta dari siswa sebanyak 15 orang siswa sedangkan peserta dari mahasiswa Program Studi Teknik lingkungan sebanyak 10 orang mahasiswa. Kegiatan ini diawali dengan 
praktek/coaching clinic edukasi pemilahan sampah sambil memberikan materi sosialisasi dan edukasi yang berisikan penjelasan pengetahuan tentang kelompok dan jenis sampah seperti sampah organik dan sampah non-organik, sampah daur ulang dan jenis sampah residu, serta cara penanganannya.

Dalam melakukan pengolahan sampah, pemisahan jenis sampah merupakan langkah awal dalam melakukan berbagai jenis pengolahan sampah. Dengan kata lain pemisahan jenis sampah merupakan kunci untuk melakukan pengelolaan dan pengolahan sampah. Praktik pemisahan sampah kebanyakan tidak dapat terlaksana dikarenakan kesadaran masyarakat untuk peduli lingkungan dan mengelola sampah masih kurang. Hal ini dapat terlihat pada kondisi sampah dari masyarakat yang ditampung dibeberapa TPS dan TPA yang masih tercampur. Pemisahan sampah penting dilakukan untuk memudahkan pengolahan sampah di tahap selanjutnya (Kuniaty, dkk., 2016 ).

Dalam kegiatan PKM ini setelah melakukan pengumpulan, pemilahan dan penimbangan sampah kegiatan selanjutnya adalah melakukan analisis terhadap sampah yang diperoleh. Substansi dari proses analisis tersebut adalah komposisi sampah yang terdiri dari komponen jenis sampah, potensi daur ulang sampah, dan residu sampah. Hasil analisis tersebut dapat dilihat pada tabel 1 dan infografis komposisi sampah dapat dilihat pada gambar 6 .

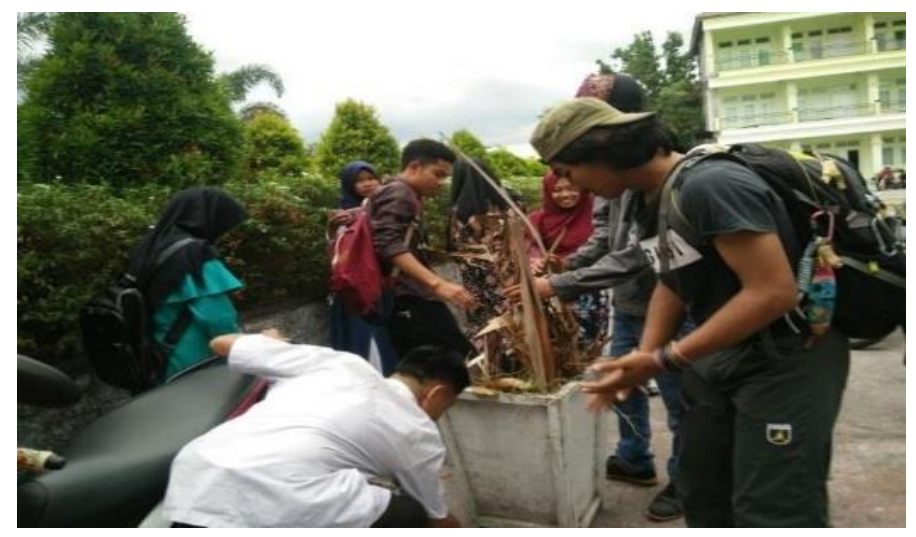

Gambar 4. Proses pengumpulan sampah

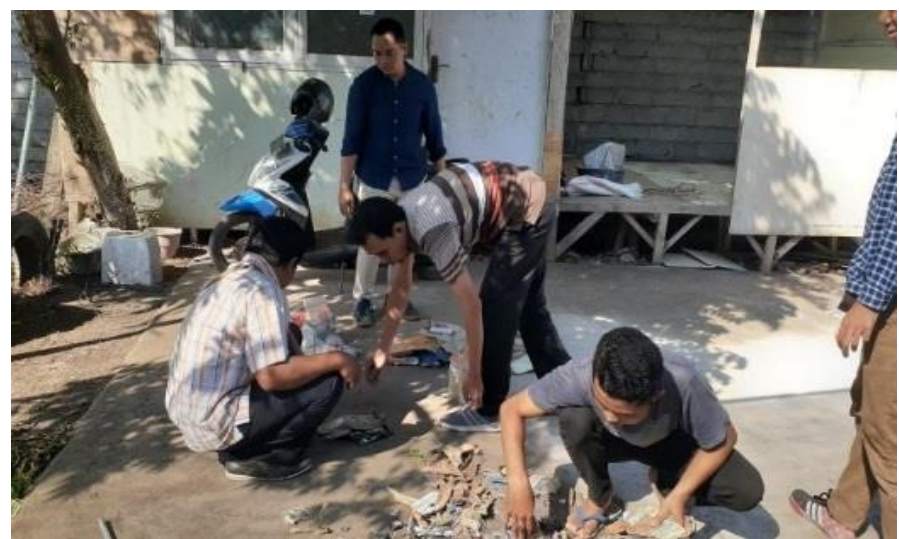

Gambar 5. Proses pemilahan sampah 


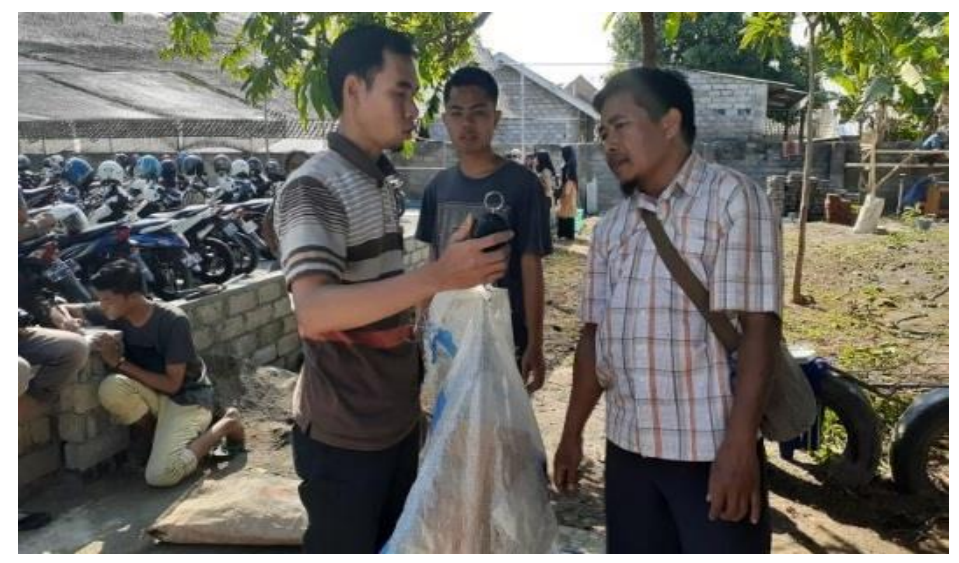

Gambar 6. Proses penimbangan sampah

Tabel 1. Hasil analisis komposisi sampah

\begin{tabular}{clcc}
\hline No & Jenis sampah & Potensi daur ulang (\%) & Residu (\%) \\
\hline 1 & Organik & 51.5 & 0 \\
2 & Kertas & 0.52 & 4.68 \\
3 & Karet/kulit & 0 & 0.09 \\
4 & Plastik & 4.22 & 8 \\
5 & Kaca & 5.5 & 2.36 \\
6 & Kain & 0 & 0.53 \\
7 & Logam & 12.44 & 0 \\
8 & Styrofoam & 0 & 0.27 \\
9 & Kayu & 0 & 7.51 \\
10 & B3 & 0 & 0.44 \\
11 & Puntung rokok & 0 & 1.78 \\
12 & Lain-lain & 0 & 0.16 \\
\hline & Sub total $(\%)$ & 74.18 & 25.82 \\
\hline
\end{tabular}

Total $(\%)$

100 


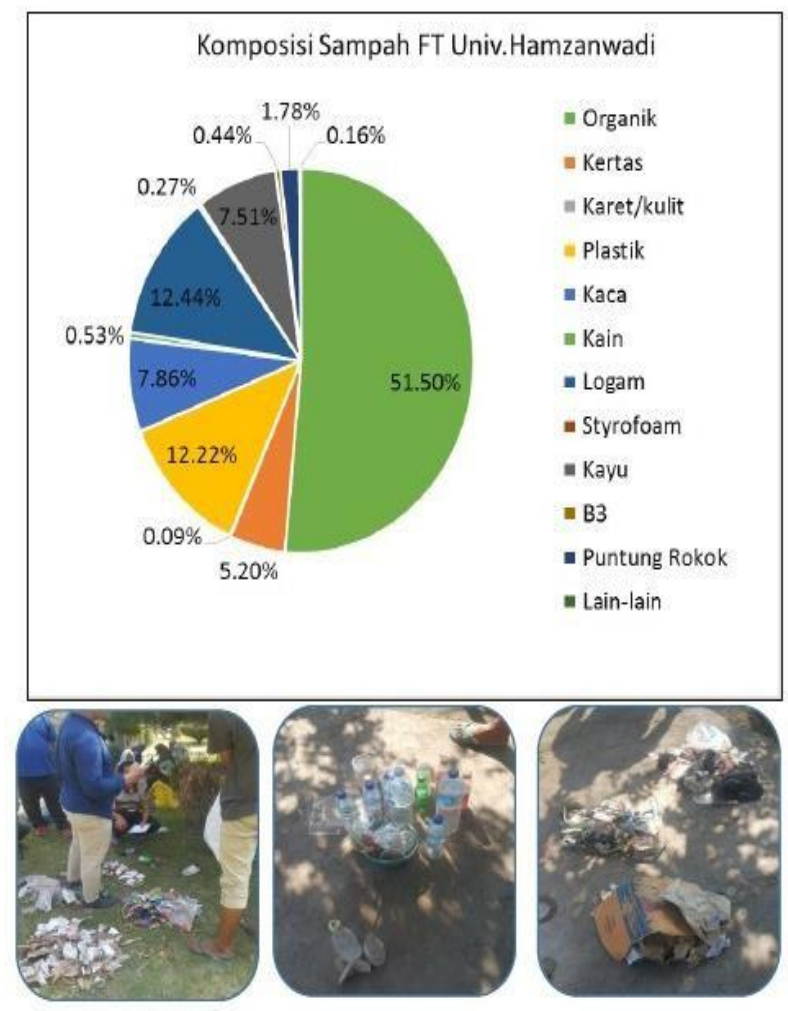

- Estimasi Nilai Kalor $=3.417,57 \mathrm{kkal} / \mathrm{kg}$ (potensi nilai kalor yang terkandung dalam sampah)

- Estimasi potensi sampah daur ulang (potensi sampah organik yang dapat dikomposkan, potensi sampah kering yang dapat didaur ulang/dijual ke pengepul sampah) dan residu (sampah yang akan dibuang ke Tempat Pemrosesan Ahir (TPA) sampah)

\begin{tabular}{|l|c|c|}
\multicolumn{1}{r|}{ Jenis Sampah } & Potensi Daur Ulang (\%) & Residu (\%) \\
\hline Organik & 51.5 & 0 \\
\hline Kertas & 0.52 & 4.68 \\
\hline Karet/kulit & 0 & 0.09 \\
\hline Plastik & 4.22 & 8 \\
\hline Kaca & 5.5 & 2.36 \\
\hline Kain & 0 & 0.53 \\
\hline Logam & 12.44 & 0 \\
\hline Styrofoam & 0 & 0.27 \\
\hline Kayu & 0 & 7.51 \\
\hline B3 & 0 & 0.44 \\
\hline Puntung Rokok & 0 & 1.78 \\
\hline Lain-lain & 0 & 0.16 \\
Sub Total (\%) & 74.18 & 25.82 \\
Total (\%) & & 100 \\
\hline
\end{tabular}

Analisa: Program Studi Teknik Lingkungan Universitas Hamzanwadi

Gambar 7. Infografis komposisi sampah

Kegiatan terakhir dalam kegiatan ini adalah pendampingan pembuatan tempat sampah organik dari kawat. Alasan memilih jenis ini adalah karena bahannya mudah di dapatkan, kuat, dan tahan laman. Alat dan bahan yang digunakan adalah kawat ukuran 3 meter, kawat pengait, dan tang (pemotong kawat). Cara membuatnya juga sangat mudah, kawat di gulung dengan diameter sekitar 1 meter kemudian kedua ujungnya diikat dengan kawat pengait. Setelah jadi tempat sampah organik dari kawat kemudian diikat atau dipasak di batang pohon atau ditempelkan ditembok. Sampah yang diisi dibiarkan sampai penuh dan membusuk sendiri. Setelah bagian bawah membusuk bisa dibolak-balik atau diambil menjadi pupuk organik.

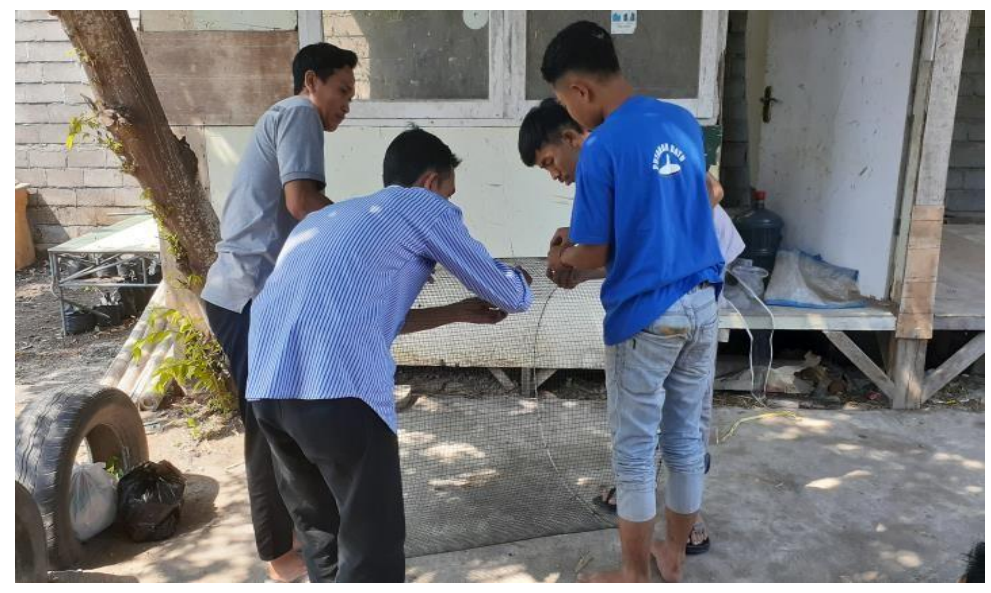

Gambar 8. Proses pembuatan tempat sampah organik 


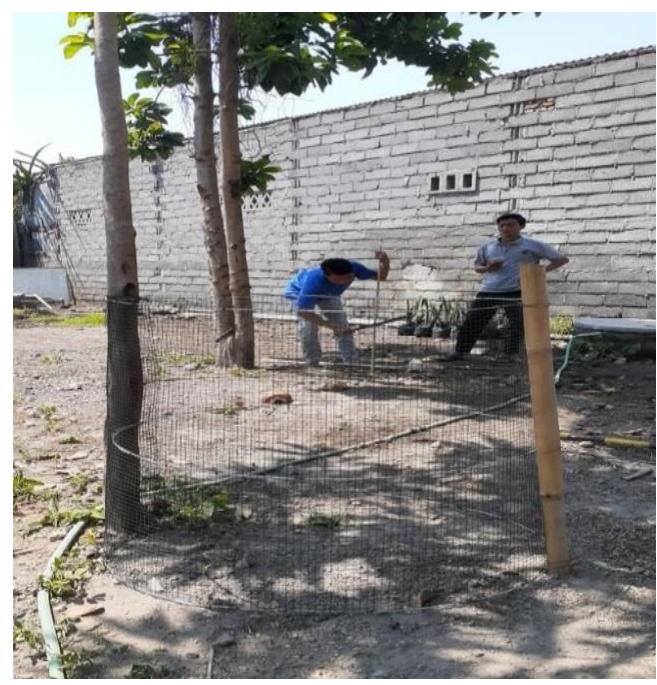

Gambar 8. Tempat sampah organik yang sudah jadi

\section{PEMBAHASAN}

Pada kegiatan sosialisasi mengenai Zero Waste respon dan antusias dari peserta cukup baik, pelaksanaaan sosialisasi dan transformasi pengetahuan dari tim PKM berjalan lancar. Pada kegiatan demonstrasi pengolahan limbah rumah tangga yaitu praktik mengolah minyak jelantah menjadi sabun dan lilin, peserta terlihat antusias dan merasakan kegiatan ini sangat bermanfaat untuk diterapkan karena dapat memanfaatkan limbah minyak jelantah yang biasanya dibuang begitu saja ternyata dapat dimanfaatkan menjadi sabun dan lilin yang lebih bermanfaat. Selain itu produk-produk yang dihasilkan seperti sabun dan lilin ini bila dikembangkan dapat menjadi peluang usaha untuk menambah penghasilan keluarga terutama dimasa pendemi. Sebagaimana dengan kegiatan yang dilakukan oleh tim PKM Universitas Negeri Malang di Desa Sumbergondo Kota Batu Malang, setelah diberikan pelatihan rata-rata 90\% peserta menyatakan kesanggupan untuk melakukan penjualan produk lilin dari minyak jelantah baik secara langsung maupun melalui perantara (Aini, dkk., 2020). Selain itu di Desa Taktakayang Serang Banten telah dihasilkan pula produk sabun pembersih lantai dari minyak jelantah dengan nama "Milanpell Harumasan" yang merupakan hasil karya ibu-ibu rumah tangga di desa tersebut (Sumiati, dkk., 2019). Penggunaan metode PLA pada kegiatan ini ternyata mendapatkan hasil yang sangat baik, hal ini sejalan dengan kegiatan pengabdian yang dilakukan oleh Putra, dkk. (2020) yang menggunakan metode PLA sebagai metode untuk pelatihan peningkatan kompetensi siswa.

\section{SIMPULAN}

Simpulan dari kegiatan pengabdian ini adalah meningkatnya pengetahuan dan terbangunnya komitmen kelompok masyarakat dalam menerapkan pola hidup zero waste yang ditandai dengan antusiasme peserta dalam memberikan feedback bagi tim pelaksana. Selain itu adanya peningkatan upaya perlindungan dan pengelolaan lingkungan hidup yang ditandai dengan adanya komitmen para siswa untuk melaksanakan upaya pengelolaan sampah berkelanjutan disekolah serta terjalinnya kerjasama antara universitas dengan sekolah serta kelompok masyarakat atas itikad bersama dalam mendukung dan mewujudkan program NTB

\section{PERNYATAAN PENULIS}


Artikel ini merupakan hasil karya sendiri yang belum pernah dipublikasikan baik secara keseluruhan maupun sebahagian, dalam bentuk jurnal, working paper atau bentuk lain yang dipublikasikan secara umum. Karya ilmiah ini sepenuhnya merupakan karya intelektual dan seluruh sumber yang menjadi rujukan dalam karya ilmiah ini telah sebutkan sesuai kaidah akademik yang berlaku umum, termasuk para pihak yang telah memberikan kontribusi pemikiran pada isi, kecuali yang menyangkut ekspresi kalimat dan disain penulisan.

\section{DAFTAR PUSTAKA}

Aini, D. N., Arisanti, D. W., Fitri, H. M., \& Safitri, L. R. (2020). Pemanfaatan Minyak Jelantah Untuk Bahan Baku Produk Lilin Ramah Lingkungan Dan Menambah Penghasilan Rumah Tangga Di Kota Batu. Warta Pengabdian, 14(4), 253-262.

Fatmawati, B., Adriandani, N., \& Fajri, N. (2020). Edukasi Zat Aditif Melalui Demonstrasi Kimia di MA NW Ridlol Walidain Batu Bangka. ABSYARA: Jurnal Pengabdian Pada Masyarakat, 1(1), 1-9.

Ginting, D., Wirman, S. P., Fitri, Y., Fitrya, N., Retnawaty, S. F., \& Febriani, N. (2020). PKM Pembuatan Sabun Batang Dari Limbah Minyak Jelantah Bagi IRT Kelurahan Muara Fajar Kota Pekanbaru. Jurnal Pengabdian UntukMu NegeRI, 4(1), 74-77.

Prajati, G., \& Darwin, D. Perilaku Guru dan Pegawai Sekolah terhadap Penerapan Program Zero Waste di Sekolah: Studi Kasus SMK Maitreyawira Batam. Jurnal Teknologi Rekayasa, 2(1), 39-46. Hanum, Y. (2016). Dampak Bahaya Makanan Gorengan bagi Jantung. Keluarga Sehat Sejahtera. Vol 14 (28), Hal: 103-114.

Kompas (2019, Februari 21). 5 Jenis Sampah Terbanyak di Bumi, dari Puntung Rokok hingga Styrofoam. https://sains.kompas.com/read/2019/02/21/200000223/5-jenis-sampahterbanyak-di-bumi-dari-puntung-rokok-hingga-styrofoam?page=all

Kusumaningtyas, R. D., Qudus, N., Putri, R. D. A., \& Kusumawardani, R. (2019). Penerapan teknologi pengolahan limbah minyak goreng bekas menjadi sabun cuci piring untuk pengendalian pencemaran dan pemberdayaan masyarakat. Jurnal Abdimas, 22(2), 201-208.

Mardiana, S., Mulyasih, R., Tamara, R., \& Sururi, A. (2020). Pemanfaatan Limbah Rumah Tangga Minyak Jelantah dengan Ekstrak Jeruk dalam Perspektif Komunikasi Lingkungan di Kelurahan Kaligandu. Jurnal SOLMA, 9(1), 92-101.

Mardikanto, T., \& Poerwoko S. (2012). Pemberdayaan Masyarakat Dalam Perspektif Kebijakan Publik. Bandung. Alfabeta

Putra, Y. K., Sadali, M., Fathurrahman, F., \& Mahpuz, M. (2020). Pelatihan uji kompetensi keahlian siswa sekolah kejuruan menggunakan metode Participatory Learning and Action (PLA). ABSYARA: Jurnal Pengabdian Pada Masyarakat, 1(2), 80-86.

Sumiati, S., Munandar, T. A., Febriasari, A., Suryaman, S., Sulasno, S., \& Dwijayanti, A. (2019). Pemberdayaan Kelompok Ibu Rumah Tangga Melalui Pembentukan Home Industry Sabun Pencuci Lantai Berbahan Dasar Limbah Minyak Jelantah. AlKhidmat, 2(1), 29-33. 
Trapsilowati, W., Mardihusodo, S. J., Prabandari, Y. S., \& Mardikanto, T. (2015). Pengembangan Metode Pemberdayaan Masyarakat Dalam Pengendalian Vektor Demam Berdarah Dengue Di Kota Semarang Provinsi Jawa Tengah (Developing Community Empowerment for Dengue Hemorrhagic Fever Vector Control in Semarang City, Central Java Province). Buletin Penelitian Sistem Kesehatan, 18(1), 20932.

Trihadiningrum, Y. (2012). Perkembangan paradigma pengelolaan sampah kota dalam rangka pencapaian Millenium Development Goals. ITS Surabaya. Fakultas Teknik Sipil dan Perencanaan.

Undang-Undang Republik Indonesia Nomor 18 tentang Pengelolaan Sampah. (2008). Jakarta. Kementerian Hukum dan Hak Asasi Manusia.

Erviana, V. Y. (2019). Pelatihan pengolahan minyak jelantah menjadi sabun dan strategi pemasaran di desa Kemiri. Jurnal Pemberdayaan: Publikasi Hasil Pengabdian Kepada Masyarakat, 3(1), 17-22.

Wirasasmita, R. H., Arianti, B. D. D., Uska, M. Z., Kholisho, Y. N., \& Wardi, Z. (2020). Edukasi Zero Waste berbasis teknologi informasi. ABSYARA: Jurnal Pengabdian Pada Masyarakat, 1(2), 35-42.

Yolanda R., 2019. Kreatifivitas Pemanfaatan Minyak Jelantah Menjadi Lilin. Jakarta. Balai Besar Pengembangan Latihan Masyarakat. Tersedia di https://bbplmjakarta.kemendesa.go.id/view/detil/621/kreativitas-pemanfaatan-minyak-jelantah$\underline{\text { menjadi-lilin }}$

Kurniaty, Y., Nararaya, W. H. B., Turawan, R. N., \& Nurmuhamad, F. (2016). Mengefektifkan Pemisahan Jenis Sampah Sebagai Upaya Pengelolaan Sampah Terpadu Di Kota Magelang. Varia Justicia, 12(1), 135-150.

Zaman, A. U. (2014). Roadmap Towards Zero Waste Cities. International Journal of Waste Resources. 4(2), 100-106. 